\title{
O DISCURSO DE AMOR NA VIOLÊNCIA CONTRA MULHERES Análise sociológica de "Quem matou Eloá”
}

\section{Túlio Cunha Rossi}

D http://orcid.org/0000-0003-4391-7268

Departamento de Ciências Sociais de Campos (COC), Universidade Federal Fluminense (UFF), Campos dos Goytacazes - RJ, Brasil. E-mail: tuliorossi@gmail.com

DOI: $10.1590 / 3510220 / 2020$

\section{Introdução}

Este artigo consiste em uma análise sociológica do documentário Quem matou Eloá (Perez, 2015), referente ao sequestro e assassinato da adolescente Eloá Cristina, de 15 anos, em outubro de 2008, por seu ex-namorado, Lindemberg Alves, em um condomínio popular na cidade de Santo André- SP. O caso atraiu o interesse de veículos da imprensa televisiva brasileira, que ofereceu ampla cobertura ao longo dos cinco dias de sequestro, até culminar em uma intervenção malsucedida da Polícia Militar de São Paulo, com a prisão do sequestrador após este disparar contra Eloá e sua amiga Nayara, também mantida refém. Eloá faleceu no hospital, vítima de um tiro no rosto e outro na regiáo da virilha, enquanto Nayara sobreviveu, tendo levado um tiro

Artigo recebido em: 14/05/2019

Aprovado em: 22/08/2019 na boca. Chamou a atenção, neste caso em particular, a participação da mídia televisiva durante o sequestro, em contato direto com o sequestrador em rede nacional.

A análise sociológica desta produção se justifica como parte de uma reflexão mais densa que, a um só tempo, problematiza o lugar e as relaçóes específicas de mídias audiovisuais nas sociedades contemporâneas, bem como as articula à própria constituição de percepçóes acerca de relaçooes íntimas e afetivas; estereótipos de gênero - com destaque para o feminino - e a violência contra as mulheres ${ }^{1}$. Isto posto, longe de recorrer ao documentário como ilustração da realidade, no que se refere a essa forma de violência, problematiza-se, metalinguisticamente, o lugar das imagens, das mídias audiovisuais e das tecnologias de comunicação na construção social da realidade, incluindo percepçóes de gênero e ideais de relacionamentos afetivos e sexuais. 
Assim, realiza-se uma análise fílmica conforme as orientaçóes metodológicas da sociologia do cinema de Pierre Sorlin (1985), reconhecendo que o filme evoca elementos e percepçóes do contexto histórico e social no qual é produzido. A sociologia do cinema é articulada a outros estudos que relacionam mídia e sociedade em seu aspecto cultural (Williams, 2016; Muanis, 2014), conferindo atenção à mídia televisiva, devido à sua presença significativa, tanto no evento que serve de mote ao filme, quanto no próprio filme em si. Ainda em relação a questóes de mídia e imagem, estabelecendo suas conexôes com o gênero, trabalha-se à luz das reflexôes de Teresa di Lauretis (1994), que reconhece o cinema - entre outras mídias - como espécie de tecnologia social com importante papel na construção de gêneros a partir de suas representaçóes. A análise dialoga com as temáticas de gênero e violência contra as mulheres, entendendo gênero enquanto "forma primária de dar significado às relaçóes de poder" (Scott, 1995, p.86), ao mesmo tempo em que são mobilizadas e discutidas referências como Heleieth Saffioti (2004) e Wânia Pasinato (2010), para abordar os significados da violência contra as mulheres dentro do contexto brasileiro. Por último, são feitas conexóes com estudos em sociologia das emoções (Chaumier, 1999; Cancian, 1986), no sentido de observar, em sua dimensão cultural, a significação de relacionamentos íntimos amorosos e como estes se articulam para configurar os cenários dos quais emergem casos de violência contra mulheres, praticados por seus namorados, ex-namorados, cônjuges e afins.

\section{Informaçóes sobre filme e seu contexto de produçáo}

O filme foi realizado com recursos do I Edital Carmen Santos de Cinema, iniciativa da Secretaria do Audiovisual do Ministério da Cultura, Secretaria de Articulação Institucional e Açóes Temáticas da Secretaria de Políticas para as Mulheres². Quem Matou Eloá foi concluído em 2014, e lançado internacionalmente no ano de 2015, participando da seleção oficial de várias mostras e festivais nacionais e internacionais de documentários e filmes curtas-me- tragens independentes, tais como a IX Mostra Outros Cinemas (Fortaleza/Brasil); a 12eme Brésil en mouvements (Paris/França); o $27^{\circ}$ Festival Internacional de Curtas-metragens de São Paulo (São Paulo/Brasil) e o IX Encuentro Hispanoamericano de Cine Y Video Documental Indepiendente (Cidade do México/México), entre outros ${ }^{3}$. O filme também acumula premiaçóes, tais como a de melhor filme (categoria mulheres) no IX Encuentro Hispanoamericano de Cine Y Video Documental Indepiendente; melhor curta-documentário no GENII Awards, Alliance for Women in Media Southern California; melhor curta-metragem nacional e menção honrosa de filme para reflexão, no $9^{\circ}$ Festival de Cinema de Triunfo ${ }^{4}$.

Há que se destacar, no contexto de produção do filme, a sua concomitância com a tramitação e os debates, na câmara e no Senado, que culminaram no texto da lei no 13.104 , publicado em 09 de março de 2015, que prevê "o feminicídio como circunstância qualificadora do crime de homicídio”. O texto da lei tem origem no Projeto de Lei do Senado - PLS 292 de 2013, fruto do trabalho de Comissão Parlamentar Mista de Inquérito do Congresso Nacional - CPMI - de Violência Contra a Mulher, instalada em fevereiro de 2012. O feminicídio é qualificado como crime de homicídio contra a mulher, por "razões da condição de sexo feminino"; sendo considerado que há razóes para essa condição, "quando o crime envolve: I - violência doméstica e familiar; II - menosprezo ou discriminação à condição de mulher" (Lei 13.104/2015).

O caso de Eloá, tanto por suas características, quanto pela grande repercussão midiática, seria tomado, ao lado de outros, como exemplo e símbolo do tipo específico de crime que a referida lei se propôs a qualificar. Nesse sentido, a produção desse filme situa-se em um momento de intensa e visível mobilização, tanto na esfera civil quanto política, no combate à violência contra a mulher, no país. Indo nesse sentido, o I Edital Carmen Santos de Cinema, de 2013, voltado especificamente para realizadoras do sexo feminino, proveu recursos para esse filme, com base em um contexto de promoçáo à igualdade de gênero, visibilidade e reconhecimento do trabalho de mulheres com alguma chancela do poder público federal, diferentemente do que se pode observar no âmbito político nacional, pelo menos desde o ano de 2016. 
Estas informaçóes contribuem tanto para a compreensão da importância de Quem matou Eloáenquanto produção fílmica nacional -, quanto de seu papel pedagógico, não apenas de denúncia e combate à violência contra a mulher, em sentido amplo e abstrato, mas também contribuindo para o reconhecimento e identificação de um tipo bastante específico de homicídio, que decorre de "razões da condição do sexo feminino", que trazem à tona a própria construção social e cultural dessas condiçôes, a qual escapa às definiçóes presumidamente "neutras" de sexo, pautadas pelo viés biológico. Aqui, concordamos com Guacira Lopes Louro (2008, p.82), quando afirma que:

uma das formas mais significativas e persistentes da combinação cinema e sexualidade pode ser examinada nos filmes propriamente ditos, nas idéias que eles nos "convocam a visitar", como diria Badiou (2004), ou nas pedagogias culturais que eles exercitam. É dessa dimensão que desejo me ocupar. Estou convencida de que os filmes exerceram e exercem (com grande poder de seduçáo e autoridade) pedagogias da sexualidade sobre suas plateias (Louro, 2000). Parece pertinente assinalar que tomo a sexualidade como um "dispositivo histórico", como dizia Foucault (1988); portanto, antes de vê-la como um "dado da natureza", compreendo-a como um constructo cultural, em que se arranjam linguagens, corpos, gestos, rituais. Assumo que os significados que se atribuem a identidades, jogos e parcerias sexuais são situados e disputados historicamente e, ao longo dos tempos, nos filmes, posiçóes-de-sujeitos e práticas sexuais e de gênero vêm sendo representadas como legítimas, modernas, patológicas, normais, desviantes, sadias, impróprias, perigosas, fatais, etc.

O reconhecimento dessas condiçóes e o questionamento de suas origens nos levam, invariavelmente, ao reconhecimento de sua constituição social e histórica, o qual por sua vez, transcende as percepçôes pretensamente objetivas limitadas ao corpo e à materialidade, para trazer à evidência a relevância da dimensão cultural, inclusive da for- mação da própria subjetividade - no que se refere aos afetos -, na construçấo social da realidade. Desse modo, o termo "gênero" é empregado, no presente texto, enquanto categoria de análise, à luz da perspectiva de Joan Scott (1995), atentando tanto para os aspectos históricos quanto relacionais dessa categoria, os quais geralmente não considerados sob a categoria sexo, utilizada no texto da lei. Segundo Scott (1995, p.72):

O termo "gênero" enfatizava igualmente o aspecto relacional das definiçóes normativas da feminilidade. Aquelas que estavam preocupadas pelo fato de que a produção de estudos sobre mulheres se centrava nas mulheres de maneira demasiado estreita e separada utilizaram o termo "gênero" para introduzir uma noção relacional em nosso vocabulário analítico. Segundo esta visão, as mulheres e os homens eram definidos em termos recíprocos e não se poderia compreender qualquer um dos sexos por meio de um estudo inteiramente separado.

\section{A construçáo narrativa em Quem Matou Eloá}

A apresentação dos créditos iniciais aos órgãos colaboradores para a produção do filme ocorre ao som de um ruído mecânico crescente, que depois pode ser identificado como o som de um helicóptero em voo. Contudo, na primeira imagem do filme, a câmera está voltada para um límpido céu azul, no qual se vê apenas uma ave negra - um urubu - em voo solitário. O desencaixe entre som e imagem, provocativo, sugere uma articulação nada natural entre a ave o ruído mecânico. Em seguida, há um corte para uma imagem aérea, com o logotipo de uma rede de televisão brasileira, sobre um conjunto habitacional que será identificado, mais adiante, como popular. As imagens permitem ver pavilhóes de prédios com pintura desgastada, e sem qualquer luxo em sua fachada. A partir desse momento, som e imagem se encaixam, principalmente com a entrada do áudio de apresentadores de televisão que, aos poucos, situam o espectador. Há novo corte 
para a apresentadora Sonia Abrão, com a legenda informando que ela conversa, ao vivo, com uma jovem mantida refém, dentro de um dos prédios do condomínio anteriormente visualizado. Aos poucos, imagens do céu, com mais urubus, são intercaladas a imagens da cobertura jornalística de diferentes emissoras de televisão. A associação é direta: os animais que sobrevoam cadáveres, interessados em se alimentar deles - ou, no caso, da tragédia que os produzem - representam a imprensa, mais especificamente, a imprensa televisiva sensacionalista. A seguir, há um corte para o céu repleto de urubus, que remete à ampla "cobertura" - literal e metafórica - da imprensa sobre o caso, mas pode igualmente remeter aos espectadores, cuja atenção foi atraída para o acontecimento.

Ao som da fala de um dos apresentadores de televisão, dizendo que "o brasileiro não tirou os olhos da televisão", há a imagem de urubus pousados, lado a lado, remetendo a espectadores reunidos na frente da televisão. A associação é mais evidente quando as imagens saem da cobertura dos jornais, para, em seguida, mostrar a tela da televisão em um restaurante movimentado. Aqui, para reforçar a metáfora e transferi-la aos espectadores, é particularmente interessante a escolha do cenário de um restaurante em horário de grande movimento: se os urubus são animais que se alimentam do produto de tragédias, a sequência que passa das aves empoleiradas, como que na expectativa de um banquete, para um espaço onde se alimentam potenciais espectadores - interessados ou acidentais - parece anular qualquer possibilidade de isenção do público frente ao espetáculo apresentado pela televisão.

Em seguida, há um corte para uma tela de um site de buscas pesquisando o nome da vítima, Eloá, e, logo após, é mostrada uma extensa lista de vídeos. Essa sequência já remete menos ao papel da imprensa e mais à curiosidade do usuário que desejar se informar a respeito do episódio. Esse conjunto de observaçóes iniciais é importante, para que não se caia na leitura simplificada da demonização das grandes mídias, como agentes completamente autônomos exercendo um poder vertical e centralizado sobre seus espectadores, opiniōes e sensaçóes. Contudo, após essa apresentação inicial, parece ser este o tom que o filme assume - ao mesmo tem- po em que usa a repercussão do caso na imprensa, visando enfatizar o "desespero" do assassino e também o discurso do crime passional cometido por um rapaz sem antecedentes criminais -, para, então, entrar na pauta do feminicídio.

A forma como o documentário é estruturado - selecionando especialistas de diferentes áreas para darem seus pareceres sobre o caso, a partir de "diferentes" pontos de vista, intercalando imagens de programas jornalísticos e de variedades da TV aberta, incluindo entrevistas com representantes da polícia -, remete, em parte, a outros documentários brasileiros de grande repercussão que também tematizaram a violência: Ônibus 174 (Padilha; Lacerda, 2002) e Notícias de Uma guerra particular (Salles; Lund, 1999). A própria maneira como o presente documentário se encerra, com a leitura em voz off de nomes de várias vítimas de feminicídio, como se os nomes parecessem se sobrepor e se embaralhar, remete ao final de Notícias de uma guerra particular, em que a tela é gradualmente preenchida pelos nomes de vítimas da guerra que o documentário tematiza. Nestes três documentários, há referências tanto à atuação da imprensa televisiva na cobertura da violência, quanto à sua relação - filmicamente construída como direta - com as desigualdades social e racial no país. Porém, Quem matou Eloá se distingue explicitamente dos outros dois, pois não versa sobre a percepção genérica da centralidade das desigualdades sociais no Brasil quanto à constituição do problema da violência. Diferentemente dos outros filmes citados, trata-se de uma forma de violência bastante específica, que atinge exclusivamente mulheres, em razão de sua condição de gênero.

O filme de Lívia Perez aborda a violência contra a mulher, construindo seu argumento, como os demais filmes, a partir das conexóes entre esta forma específica de violência, a atuação do Estado - principalmente através do aparato repressor da polícia - e a participação dos meios de comunicação de massa na mediação e construção imagética e narrativa dessa violência para o grande público. Os três documentários, de alguma maneira, sustentam críticas à atuação da polícia, sendo que os dois primeiros conduzem à questão do uso excessivo e arbitrário da força policial contra indivíduos, cri- 
minosos ou não, oriundos de camadas populares desfavorecidas - nominalmente, negros e favelados. Por sua vez, Quem matou Eloá apresenta uma crítica - em sentido aparentemente inverso - à inércia da polícia, por ter estendido uma negociação infrutífera com o sequestrador, por cinco dias. A problematização feita à não atuação policial acaba funcionando, no documentário, como elemento representativo e reiterativo dos recorrentes casos desse tipo de violência, em que as denúncias, muitas vezes, não são sequer investigadas, pois são entendidas como simples desentendimentos passageiros e de foro íntimo, que não justificariam a intervenção das forças policiais.

Seguindo as recomendaçóes analíticas de Pierre Sorlin (1985), buscamos identificar primeiramente os "sistemas relacionais" que conduzem a narrativa. Estes se referem, basicamente, ao modo como as relaçóes entre os personagens e a narrativa é organizado, ao longo da produção: "Colocando em relação indivíduos e grupos, cada filme constitui, no interior do mundo fictício da tela, hierarquias, valores, redes de intercâmbios e influências" (Sorlin, 1985, p.202). Mais adiante, o mesmo autor pontua que:

A organização do relato [cinematográfico] não é nunca o simples ato de acionar as visualizaçôes abertas pela lógica narrativa: ela revela, através do desenvolvimento de uma visão, um juízo sobre os fatos passados; é plenamente ideológica na medida em que, partindo de uma situação, reconstrói seus dados fundamentais e depois interpreta seu desenvolvimento (Sorlin, 1985, p.203) ${ }^{6}$.

Identificar as redes de relações construídas no filme permite não apenas decifrar sua construção narrativa em particular, mas igualmente os pontos de vista, sistemas de valores e de pensamento que a orientam, em seu contexto de produção. De modo semelhante, a construção e [re] organização fílmica dos recortes das sequências televisivas à época do acontecimento, bem como o seu encadeamento com as intervençóes das convidadas e convidado sobre o episódio, anos após o ocorrido, promovem uma importante reconstrução daquele fato passado, de maneira distanciada do frenesi midiático da oca- sião. Nesse sentido, o documentário - ao reconstituir acontecimentos passados e buscar a avaliação de comentadores tomados como especialistas - parece se propor, a partir mesmo de seu título, ao desafio de responder à questão: Quem matou Eloá?

Para fins estritamente analíticos, podem-se identificar dois eixos na rede de relaçóes construída no filme. O primeiro deles se refere aos cinco espectadores "especialistas" que, ao longo do documentário, são mostrados ora assistindo a excertos da cobertura televisiva da época, por meio de um telão, ora em primeiro plano, falando para a câmera sobre o acontecimento, na condição de entrevistados. Já o segundo eixo de relaçôes é constituído dentro do próprio episódio, pelo mosaico de cenas de diferentes canais de televisão para a cobertura do caso. Neste último eixo, podem ser identificados quatro "personagens" centrais: a mídia televisiva - envolvendo programas de variedades, como $A$ tarde é sua, de Sônia Abrão -, a cobertura jornalística e a atuação direta da imprensa em contato com o sequestrador, durante o ocorrido; o próprio sequestrador, Lindemberg Alves; a Polícia Militar do Estado de São Paulo e a vítima Eloá, junto com sua amiga Nayara. O grupo dos espectadores/especialistas é, de certa forma, organizado em correspondência com os personagens do episódio: Esther Hamburger, professora da ECA-USP, comenta mais especificamente o papel da mídia; o promotor Augusto Rossini, do Estado de São Paulo [que participou das negociaçóes e foi entrevistado na ocasião ], trata da atuação da polícia; as militantes ${ }^{7}$ Analba Teixeira e Elisa Gargiulio tecem, de maneira mais ampla, consideraçôes sobre a violência contra a mulher; e, por fim, a defensora pública Ana Paula Lewin toma como ilustração o sequestrador Lindemberg, para , aos 15 minutos do filme, fazer uma síntese da caracterização dos agressores típicos nessa forma de crime, enquanto réus primários.

Curiosamente, o filme não identifica seus especialistas, durante seus depoimentos. Seus nomes e ocupações aparecem apenas nos créditos finais, à exceção do promotor do Estado de São Paulo, que é identificado em uma das cenas da cobertura jornalística do acontecimento, criticando comedidamente a atuação da imprensa. Dessa forma, considerando que todos esses espectadores/especialistas tecem 
apreciaçóes sobre outras questóes não restritas à área que representam, a referida estruturação dos participantes não fica evidente para espectadores que desconhecem tais personagens, ou sua atuação, seja no Estado, na mídia ou na militância. De todo modo, a posição de autoridades do discurso é construída pelo filme, ao colocá-los em primeiro plano em relação à tela, assistindo à cobertura da imprensa e, em seguida, comentando e analisando criticamente o fato. Tudo isso, por si só, já confere autoridade ao discurso dessas figuras na construçáo do filme, ainda que o espectador não saiba de quem se trata.

No entanto, a presença de figuras importantes ligadas à militância feminista e ao combate à violência contra a mulher no Estado de São Paulo, possivelmente logo reconhecidas no universo militante, pode ser também interpretada como um efeito reiterativo do público visado, em primeiro lugar, por este documentário. Consequentemente, o filme estabelece uma conexáo ainda mais direta com determinado público específico; conexão esta, que não necessariamente ocorreria entre espectadores externos ao nicho de atuação política e social do Estado de Sáo Paulo e, ainda mais especificamente, da região metropolitana da cidade de São Paulo. Isso, obviamente não compromete a mensagem - didaticamente apresentada - do documentário, no tocante ao combate à violência contra a mulher, ainda que, potencialmente, retire algo de seu impacto entre os espectadores fora do circuito da militância no referido estado.

Outro aspecto interessante de se observar reside na distância temporal entre os dois eixos relacionais, aqui apontados. Nesse sentido, o período de sete anos entre o episódio e a estreia do filme é marcado também pela organização de diversos esforços de promoção, nos campos do debate público e da mídia, da Lei Maria da Penha, aprovada em 2006. Nesse sentido, há neste filme um aspecto que, às vezes, passa despercebido na "leitura documentarizante”, a qual, segundo Roger Odin (2012, p.18), é estabelecida pela "realidade pressuposta do enunciador e não a realidade do representado"; sendo o filme documentário, aquele que "integra explicitamente em sua estrutura (de um modo, ou de outro) a instruçáo de fazer acionar a leitura documentarizante: quando ele programa a leitura documentarizante" (Odin, 2012, p.23). Tal aspecto seria o da própria reconstrução do episódio sob um olhar distanciado, que reorganiza e ressignifica a interpretação, à luz de informaçôes, acontecimentos e questionamentos que não necessariamente se apresentavam, ou estavam elaborados à época do acontecimento documentado. Ao não assinalar explicitamente a distância temporal e suas implicações políticas e ideológicas, entre o evento apresentado e a realização do documentário, o filme acentua ainda mais o caráter já absurdo tanto do episódio, como da atuação da imprensa e da polícia na ocasião, mas sem contextualizá-los, seja em relação ao tema do combate à violência contra a mulher na esfera pública, seja em relação ao papel da televisão e à configuração da grade de programação, principalmente das emissoras de canais abertos.

Assim, nota-se um duplo distanciamento, neste documentário, em relação aos eventos que culminaram na morte de Eloá, por meio de efeito metanarrativo, ao construir as apreciaçóes dos especialistas não sobre o evento propriamente dito, mas sobre outra narrativa construída sobre ele, à época do acontecimento, e que lhes é apresentada igualmente de forma fragmentada e reorganizada. A percepção desse aspecto construtivo é fundamental para a problematização, tanto do feminicídio em seus aspectos mais amplos, quanto do caso específico de Eloá. A reconstrução distanciada do episódio, à luz da visibilidade do tema - posteriormente promovida por órgãos públicos e pelas militâncias ${ }^{8}$-, permite a ressignificação de vários elementos presentes no ocorrido, com destaque para o discurso do desespero amoroso, que, da forma como o documentário os apresenta, podem parecer a-históricos. Assim, uma análise sociológica da construção fílmica tal como aqui proposta expressa, a um só tempo, a necessidade de uma dupla historicidade: a primeira, sobre o caso de Eloá, em 2008; e a segunda, sobre a reconstrução do mesmo, pelo documentário em 2015. Embora a distância temporal pareça insignificante, do ponto de vista tanto da visibilidade do debate sobre a violência contra a mulher no Brasil, quanto da possibilidade de difusão deste debate - e mesmo deste documentário e de outros, sobre temáticas afins -, por meio do incremento ao acesso a mídias digitais no país ${ }^{9}$, os 
sete anos decorridos entre o episódio e o lançamento do documentário não são nada desprezíveis no discurso que este constrói.

\section{Mídia e violência contra a mulher}

Entende-se, então, que o filme atua como reforço pedagógico no combate à violência contra a mulher e ao feminicídio, reafirmando a importância da Lei Maria da Penha, entre outros recursos. De acordo com Wânia Pasinato, a Lei 11.340/2006, conhecida como Lei Maria da Penha, estaria baseada em três eixos:

O primeiro eixo trata das medidas criminais, para a puniçãao da violência. [...] No segundo eixo encontram-se as medidas de proteção da integridade física e dos direitos da mulher que se executam através de um conjunto de medidas protetivas [...] Finalmente, no terceiro eixo, estão as medidas de prevenção e de educação, compreendidas como estratégias possíveis e necessárias para coibir a reproduçáo social da violência e da discriminação baseadas no gênero (Pasinato, 2010, p. 220).

Em síntese, a lei objetiva "coibir e prevenir a violência doméstica e familiar contra a mulher" (artigo. $1^{\circ}$ ), tipificando "violência doméstica e familiar contra a mulher", como "qualquer ação ou omissão baseada no gênero que lhe cause morte, lesão, sofrimento físico, sexual ou psicológico e dano moral ou patrimonial" (artigo. 50); podendo ocorrer "em qualquer relação íntima de afeto, na qual o agressor conviva ou tenha convivido com a ofendida, independentemente de coabitação" (idem).

Dos três eixos apresentados por Pasinato, o de prevenção e educação é o de maior interesse para o presente trabalho, ao se verificar, no texto da lei, a preocupação não somente com a realização de campanhas educativas e o "destaque nos currículos escolares [...] para conteúdos relativos aos direitos humanos e à equidade de gênero e raça ou etnia" (art. $8^{\circ}$ da lei 11.340/2006), mas também, "o respeito, nos meios de comunicaçáo social, dos valores éticos e sociais da pessoa e da família, de forma a coibir os papéis estereotipados que legitimem ou exacerbem a violência doméstica e familiar" (idem). Este último ponto tem particular relevância, ao suscitar o papel dos meios de comunicação na difusão de conteúdos fundamentais para a formação dos indivíduos e de seu comportamento em sociedade. Especialmente no caso de Eloá, em que toda a exposição midiática do episódio reforça papéis estereotipados, sobretudo na figura do agressor e suas motivaçóes "passionais". Acreditamos, assim, que ainda mais reiteradamente, sob o recurso da exemplificação, o documentário - lançado nove anos após a aprovação da lei e sete anos após o episódio narrado - insira-se neste eixo de prevenção e educação, atuando de forma didática e elucidativa para tratar da violência contra a mulher.

$\mathrm{O}$ aspecto educativo é particularmente importante para se pensar as relaçóes de gênero; sendo que, conforme já aparece sugerido no texto da lei, e também em diferentes estudos - como o já citado artigo de Louro sobre cinema e sexualidade -, ele não deve ser entendido como restrito às instituiçóes de ensino, comportando significativa participação de diferentes mídias, que, embora aparentemente não se proponham a "ensinar" sobre determinados temas, contribuem para compor o que Ruth Sabat (2001, p.19), em sua análise da publicidade, chama de currículos culturais:

Tal como o currículo escolar, o currículo cultural envolve um conhecimento organizado em torno de relaçóes de poder, de regulação e controle. Não se trata de afirmar que existe um lugar onde tal organização é detalhadamente planejada, mesmo porque tal lugar não existe. O que importa aqui é relacionar o conhecimento produzido pela publicidade com as práticas de autocontrole e auto-regulação que se concretizam na vida cotidiana, através do corpo, do comportamento, das relaçóes sociais estabelecidas.

Entende-se, assim, que produçóes, como Quem matou Eloá, oferecem também importante contribuição pedagógica, no sentido de oferecer visôes e leituras alternativas em relação a temas, como a violência contra mulheres e relacionamentos afetivos; 
explicitando as possibilidades de desconstrução, pela dimensão cultural, de práticas, crenças e valores tantas vezes vivenciados e difundidos de forma naturalizada, no tocante às relaçóes entre masculino e feminino. Mais ainda, o documentário oferece a oportunidade de contraponto frente à construção hegemônica do discurso romântico apropriado por diferentes emissoras de TV e por comentaristas do caso, à época de sua ocorrência. Dessa maneira, o filme nos coloca em contato com duas pedagogias de gênero: a primeira, da mídia televisiva, que reitera o discurso do sofrimento amoroso como elemento legitimador do descontrole de Lindemberg, associadamente, ainda, à ênfase dada à ausência de antecedentes criminais do rapaz, minimizando o caráter violento de seu ato para qualificá-lo como “desespero.” A segunda, do próprio documentário, principalmente através das consideraçóes de seus entrevistados sobre o caso.

Há dois aspectos dignos de nota, no que diz respeito ao papel da televisão, seja neste episódio específico, seja em seu aspecto sociológico mais geral. $\mathrm{O}$ primeiro diz respeito à complexa imbricação entre o espetáculo televisivo em torno do ocorrido e o ocorrido em si. A interferência da imprensa, neste episódio, foi decisiva para a atuação do sequestrador em relação à polícia, em seu processo de negociação e seu crescente ganho de confiança - sendo que, a partir do momento em que Lindemberg se torna ciente do destaque recebido na televisão ${ }^{10}$, já fica impossível saber, pelos registros em áudio de suas conversas com a polícia, quem eram os interlocutores a quem ele se dirigia: se era aos espectadores, aos jornalistas, ou à polícia. Nesse sentido, o episódio permitiu a Lindemberg interpretar um personagem em um lugar de potência que, certamente, não corresponderia ao mesmo Lindemberg que, dias antes, frustrado com o fim da relação, teria iniciado a cadeia de eventos que culminaria neste assassinato transmitido em rede nacional.

Neste caso, lembramo-nos da observação de Saffioti (2007, p.51): "O poder [...] tem duas faces: a da potência e a da impotência. As mulheres estão familiarizadas com esta última, mas este não é o caso dos homens, acreditando que, quando eles perpetram a violência, estão sob efeito da impotência”. Contudo, o lugar de potência que Lindemberg conquista frente às câmeras vai além de sua posição em um sistema que Saffioti denominaria de dominação patriarcal. Ele se afirma em um contexto mais amplo, no qual as relaçôes culturais com a mídia televisiva e os meios de comunicação de massa já se tornaram tão naturalizadas e corriqueiras, que são incorporadas, mais ou menos conscientemente, às próprias açôes dos indivíduos. No âmbito dessas relaçóes, autoras, como Teresa de Lauretis, já observaram um papel significativo para a construção e reiteração de representaçôes de gênero. Ela defende que o "gênero é uma representação", e que a "representação de gênero é a sua construção" (Lauretis, 1994, p.209); sendo que as mídias operam dentro de um conjunto de "tecnologias de gênero [...] com poder de controlar o campo do significado social e assim promover e 'implantar' representaçóes de gênero" (Lauretis, 1994, p.228). A autora se inspira parcialmente na análise foucaultiana do poder em sua relação com o sexo, mas confere especial atenção ao aparelho cinematográfico, afirmando:

A teoria do aparelho cinematográfico se preocupa mais que Foucault em responder a ambas as partes do meu questionamento inicial: não apenas o modo pelo qual a representação de gênero é construída pela tecnologia específica, mas também como ela é subjetivamente absorvida por cada pessoa a que se dirige. Para a segunda parte da questão a ideia crucial é o conceito de plateia, que a teoria feminista estabeleceu como um conceito marcado pelo gênero; o que equivale a dizer que as maneiras pelas quais cada pessoa é interpelada pelo filme, as maneiras pelas quais sua identificação é solicitada e estruturada no filme específico, estão íntima e intencionalmente sendo explicitamente relacionadas ao gênero do espectador (LAURETIS. 1994, p.222).

Em relação ao segundo aspecto digno de nota, mencionado no início do presente tópico, analisamos a seguinte fala da militante Elisa Gargiulio, a partir dos 12'50" do documentário: "Apontar a câmera para uma cena real de sequestro e editar, como se fosse um filme de ação, a ideia é subtrair a realidade do fato. Então você transforma aquilo numa 
narrativa de filme justamente para dar impressão a quem está assistindo de que aquilo não é real.” Em diversas oportunidades, autores como Jean Claude Carrière (1995) e Paulo Menezes (2001), embora falando mais especificamente de produçôes cinematográficas, já chamaram a atenção para as armadilhas das complexas relaçóes entre cinema - documentário ou não - e "realidade"; o que diz respeito especialmente à capacidade da câmera de, sem mediações, captar e transmitir, efetivamente, a realidade apresentada frente a seu mecanismo. Nessa direção, Menezes (2001, p.73), em sua análise de Laranja mecânica (Kubrick, 1971), proporciona a seguinte provocação, que merece ser aqui compartilhada:

No meio de sua apreciação do primeiro filme, quando comenta a cor do falso sangue que jorra nas telas, Alex nos brinda com uma proposição exemplar: "é gozado como as cores do mundo real só parecem verdadeiramente reais quando vistas em uma tela”. Pensamento jogado como quem não quer nada, é, entretanto, cheio de implicaçóes. O que reforça a perspectiva de que, talvez, a grande força deste filme está no que nos é mostrado e não só na história que nos está sendo contada, apesar de aparentemente as duas coisas andarem juntas e ao mesmo tempo. Uma delas nós vemos, sobre a outra nós pensamos. Só que pensamos apenas depois de termos visto o que vimos.

A contraposição entre "a realidade do fato" e sua versão midiática pouco ou nada nos ajuda a compreender o sequestro e assassinato de Eloá. Entretanto, suscitar essa contraposição e ainda inseri-la dentro do documentário, na fala de uma das personagens construídas como especialista e comentadora do episódio, pode nos dizer muito sobre as percepçóes de "realidade" que o filme evoca. A começar pela ideia de "subtrair a realidade do fato", que só parece fazer sentido num contexto em que a visibilidade da violência contra a mulher já se estabeleceu como pauta, e seu reconhecimento se dá em oposição ao silenciamento das vítimas e ocultamento de diversos casos similares que nâo ganham o mesmo apelo midiático. Contudo, a ideia de subtração de realidade, especialmente ao incorporar recursos nar- rativos que remetem a filmes, é equivocada ao ignorar a incorporação da linguagem fílmica às formas de comunicação e expressão corriqueiras nas sociedades modernas, ao longo do século XX, e naturalizadas para novas geraçôes do século XXI. Consequentemente, somos levados a questionar: seria a nossa percepção de realidade - mediada pela televisão e pelas mídias digitais e culturalmente produzida neste cenário - capaz de reconhecer "a realidade do fato", fora das estruturas narrativas em que nossa relação com a realidade, por meio de imagens de jornais, é reiteradamente construída?

Além disso, ingenuamente, atenta-se contra o próprio documentário que, nessa perspectiva, resume-se, igualmente, a uma seleção e edição criteriosas de trechos (já editados) de material televisivo, a sua livre articulação sequencial e a incorporação de discursos de personagens em papel de autoridades sobre o ocorrido. Se a televisão, supostamente, atuaria no sentido de "subtrair a realidade" do fato, ao invés de, como acreditamos aqui, exacerbá-la em certos aspectos específicos para provocar o interesse do público, será que este documentário não faria o mesmo, de forma ainda mais explícita? A questão não gira em termos de uma comparação entre quem teria o maior "coeficiente de realidade", mas, sobretudo, de trazer à tona que discursos e noçóes de realidade estáo sendo colocados em disputa, e de que, no presente contexto sociocultural, elas são penetradas e parcialmente conformadas por relações já consolidadas com produtos de mídias audiovisuais. Conforme Carrière (1995, p.81) observa em relação ao cinema, e que acreditamos ser cabível quando se trata do telejornalismo:

Encorajado por leis da probabilidade que são exclusivamente cinematográficas, [o cinema] rotineiramente retrata condutas irracionais que, não obstante, por puro hábito e inércia, parecem-nos normais. Apesar disso, simultaneamente, ele rejeita tudo o que na vida real nos parece incomum ou absurdo. [...] Coincidências, eventos improváveis - a verdade não é sempre convincente. Sempre soubemos disso. O cinema que tão frequentemente se aventura pelo irreal, constantemente renuncia a uma realidade que considera difícil demais de ser engolida. 
A incorporação de recursos narrativos cinematográficos, pela mídia televisiva, não é nenhuma surpresa. Como Raymond Williams (2016) aponta, a televisão foi uma tecnologia que se desenvolveu com foco principal na difusão e distribuição das imagens, mais do que na produção do conteúdo em si. E mesmo depois que a produção do conteúdo ganhou importância, este buscou atender de várias maneiras a demandas, a partir de uma linguagem já estabelecida não apenas pelo cinema, mas também pela publicidade, rádio, revistas e folhetins.

Portanto, a forma de apresentar a "realidade", em vista de vários desdobramentos históricos e tecnológicos, incorporou, ao longo do século XX, aspectos narrativos que prontamente remetem ao cinema, o qual, por sua vez, ocupou lugar pioneiro na relação mecânica e eletronicamente mediada entre imagem em movimento e realidade. Em outra perspectiva, Felipe Muanis (2014) aborda o caráter híbrido presente nas construçóes audiovisuais, sendo que essa hibridez pode ser observada na maneira como telejornais abordaram o caso de Eloá: ora com matizes de "jornalismo realista", ora de "último capítulo de novela", ou ainda, nas palavras de Elisa Gargiulio, de um “filme de ação”. E fazendo a conexão com a observação de Carrière, citada acima: não seria este um caso de justamente conferir a uma realidade difícil de ser engolida um mínimo de sentido, exatamente pela condução narrativa de um caso demasiadamente absurdo, se considerarmos, além do próprio crime em si, a atuação da polícia e da imprensa? Assim, parece-nos não apenas impreciso, como equivocado, sustentar o argumento de que a cobertura do caso buscou "subtrair a realidade dos fatos". Ao contrário, nota-se o esforço de construir e reiterar determinada "realidade", que só se torna palatável, ou mesmo convincente para o público, através dessa mediação estratégica e, convém dizer, jamais isenta ou imparcial.

\section{Amor, poder e violência contra a mulher}

É nessa construção da realidade expressa em telejornais, mas bebendo em fontes do cinema, novelas, e mesmo da literatura, que se veem discursos, releituras e narrativas dos acontecimentos em disputa. E nessa disputa, como aparece no documentário, destaca-se o lugar de uma narrativa tipicamente romântica que, insistentemente, coloca o agressor no lugar de "desespero" 11 e descontrole emocional face ao rompimento da relação amorosa. O amor - mais especificamente o amor-paixão acaba operando como "uma fuga ao controle social normal, fuga essa que tem, todavia, de ser tolerada pela sociedade como se fosse doença" (Luhmann, 1991, p.29). Mas, o mais curioso no que diz respeito aos atos de violência perpetrados por homens contra suas parceiras, é que, embora as sociedades ocidentais modernas tenham se habituado, através da psicanálise e de outros discursos, a tratar o descontrole emocional - incluindo a histeria - como algo tipicamente "feminino", este mesmo descontrole, quando protagonizado por um homem, converte-se em ato de violência "legitimado" por sua passionalidade.

Sob uma perspectiva feminista, Mari Luz Esteban (2011) esboça uma teoria sobre o amor, tal como ele se apresenta na cultura ocidental moderna, questionando seus aspectos idealizados e naturalizados, e chamando a atenção para, entre outros aspectos por vezes ignorados, a confusão entre reconhecimento e posse e a invisibilização de diferenças de poder implícitas no ideal amoroso ocidental. Segundo a autora:

Quer estejamos conscientes ou não, a conformaçáo hegemônica ocidental do amor é um obstáculo radical ao reconhecimento real do outro, para reconhecer-lhe um lugar no mundo. Além disso, entre nós o reconhecimento tende a ser confundido com a possessão (você é minha uma vez que eu te amo); é um amor que invisibiliza as diferenças de poder, que invisibiliza conhecimentos e tarefas (as mulheres cuidam porque eles amam, os homens trabalham), distorce a bidirecionalidade, reciprocidade e impede a partilha de trabalho e riqueza (quem ama náo pode pedir nada em troca). E tudo isso se aplica assim em especial para as mulheres e, provavelmente, também para aqueles homens que não estáo empenhados em enfatizar sua masculinidade (ESTEBAN, 2011, p.86). 
No caso de Eloá, é interessante observar não apenas que os elementos apontados por essa autora fazem-se presentes - com destaque para a ideia de possessão e a diferença de poder -, como a própria construção mostrada no documentário, feita pela cobertura televisiva do caso, acontece dentro dessa "conformação hegemônica do amor", visando elaborar uma leitura tangível do evento e, de certo modo, conferir-lhe algum sentido. Sentido esse, que se amparou, em grande parte, nas alusóes e aproximações com um imaginário romântico constituído, em grande medida, a partir do consumo de filmes, novelas e cançóes, que, ao exaltar o sofrimento amoroso, o descontrole emocional, o desespero, invisibilizam ou, ao menos, reduzem o caráter violento do episódio. Por sua vez, cabe ressaltar que esse caráter esteve presente desde o primeiro momento, quando Lindemberg recusa o "não" de Eloá; e não unicamente no desfecho do ato, quando ele dispara a arma contra ela e sua amiga. Nesse sentido, tanto a mídia televisiva, como a própria polícia, à época do ocorrido, aparentemente só reconheceram a violência intrínseca a toda aquela narrativa, em seu momento final, quando houve derramamento de sangue.

Assim, voltando ao desafio de responder à questão título - Quem matou Eloá? -, encontramos outra possibilidade de entrada mais enfática e abrangente: a cultura machista impregnada na sociedade brasileira. De acordo com Eva Blay (2003, p.96), essa cultura pode ser entendida como:

a persistente cultura de subordinação da mulher ao homem de quem ela é considerada uma inalienável e eterna propriedade; uma recorrente dramatização romântica do amor passional, sobretudo na televisão e no rádio, em que realidade e imaginário se retro-alimentam; na facilidade com que os procedimentos judiciais permitem a fuga dos réus; na pouca importância que as instituiçôes do Estado dão à denúncia e ao julgamento dos crimes contra as mulheres e meninas.

Para Saffioti (2004, p.54), isso corresponde a uma expressão do patriarcado, enquanto sistema de dominação imposto por homens sobre mulheres, respaldado nas leis e na organização da sociedade. Nesse sentido, é notável que seja presente, mesmo nos dias de hoje, uma forma de tratar a mulher como se esta fosse propriedade do homem, remetendo à observação de que, nas raízes da teoria política do contrato, "o contrato original seria um contrato entre homens onde o objeto são as mulheres" (Pateman, 1993, apud Saffioti, 2004, p.55). Uma vez concebendo a mulher desse modo, homens, percebendo-se no gozo de seus direitos sobre sua propriedade, subjugariam o corpo de suas parceiras, cerceariam sua liberdade e, conforme acreditassem ser de sua conveniência, exerceriam sua prerrogativa "natural" de agredi-las. Isso é marcante em um trecho do documentário, em que se ouve Lindemberg falando ao telefone para a polícia: "Eu tô agredindo a minha namorada, essa desgraçada aqui" "Eu não sou sua namorada" [responde Eloá]. Nesse momento do filme, ouvem-se os gritos de Eloá e a ordem de Lindemberg, para que ela cale a boca.

Aqui, a noção de dominação patriarcal apenas parece funcionar para responder à pergunta colocada no título do documentário. Não obstante, concordamos com Santos e Izumino (2005, p.158), ao afirmarem que:

Entendemos que a noção de dominação patriarcal é insuficiente para dar conta das mudanças que vêm ocorrendo nos diferentes papéis que as mulheres em situação de violência têm assumido. Defendemos uma abordagem da violência contra as mulheres como uma relação de poder, entendendo-se o poder não de forma absoluta e estática, exercido via de regra pelo homem sobre a mulher, como quer-nos fazer crer a abordagem da dominaçáo patriarcal, senão de forma dinâmica e relacional, exercido tanto por homens como por mulheres, ainda que de forma desigual.

Da maneira como o documentário é construído - reforçando a participação condescendente da mídia com essa forma de dominação - se ele, por um lado, funciona ao produzir um efeito de ênfase, tanto dramática quanto didática, sobre a gravidade não apenas do caso de Eloá, como de vários outros citados na sequência final, ele reforça, por 
outro lado, uma perspectiva de relação "absoluta e estática" de poder; ainda que as falas de conclusão das comentadoras do episódio apontem para a importância da denúncia ou de "meter a colher"12. Além disso, ironicamente, apesar da crítica de Esther Hamburger - de que: "No que a gente vê na televisão, a gente sabe mais do que faz o Lindemberg, do que o que faz a Eloá. A Eloá parece que não existe, ela é uma decorrência do Lindemberg" -, o documentário parece repetir esse procedimento; o que acaba contribuindo, involuntariamente, para reforçar a impressão de uma relação de poder estática, unilateral e naturalizada de homens sobre mulheres, perdendo de vista o caráter complexo e dinâmico, presente nessas relaçóes de poder. De modo que a compreensão - e, a partir dela, o combate - de atos de violência, como este, atravessam e se irradiam em diferentes domínios e níveis da vida social, sem que se possam desprezar os cruzamentos recorrentes com aspectos de classe e étnico raciais ${ }^{13}$.

Além disso, como o filme nos permite ver apenas superficialmente, existem concepçóes difundidas acerca dos relacionamentos íntimos e conjugais igualmente naturalizadas, que não derivam, necessariamente, da dominação masculina; sendo frequentemente percebidas e vivenciadas - ainda que, em muitos casos, ilusoriamente - como relaçóes de reciprocidade, complementaridade e, ao menos em seus estágios iniciais, isonomia. Trata-se, assim, de perspectivas de relacionamentos amorosos que, sem dúvida, contribuem para a manutenção de uma relação desequilibrada de poder e manutenção de privilégios masculinos, mas que não são suficientemente compreendidas, se abordadas unicamente sob esse aspecto.

Isso é ainda mais evidente, quando os modelos de relacionamento amoroso romântico são incorporados, reproduzidos e, muitas vezes, buscados em relacionamentos não heterossexuais. Desse modo, o documentário apenas arranha a superfície das crenças amorosas correntes no senso comum, e tão reiteradamente reforçadas na televisão brasileira, a partir de novelas, tornando o caso de Eloá ainda mais contundente: a cobertura de seu sequestro, mais do que uma narrativa de filme de ação, tornou-se, em determinado momento, como comenta Elisa Gargiulio, uma narrativa de novela, construindo a imagem do sequestrador - nas palavras de um dos apresentadores de telejornal, durante a cobertura do caso - como "menino trabalhador [que] acabou se desesperando, problema de relacionamento".

A cena em que mais se evidencia essa crença naturalizada em ideais românticos, como algo incorporado às práticas cotidianas, é quando um convidado do programa de Sônia Abrão, Dr. Ademar Gomes, apresentado como psicólogo, dá seu parecer sobre o caso, quando o mesmo parecia caminhar no sentido de um acordo entre polícia e sequestrador, com a rendição do rapaz: "Eu sou muito otimista, né? Eu espero que isso termine em pizza, num casamento futuro entre ele e a namorada, a apaixonada dele. Ele tá passando uma fase momentânea, também ter perdido a motivação de viver. Porque, muitas vezes, o rapaz jovem, quando se apaixona, se desequilibra". Vale descrever que o casamento, enquanto desfecho "feliz", é praticamente uma tradição das novelas brasileiras; de modo que a fala do psicólogo, mais do que remeter a um conjunto de crenças compartilhadas em relaçáo à vida amorosa, alude a um roteiro próprio dos folhetins televisivos. Assim, é possível questionar em que medida a interpretaçáo - equivocada ou não - de fenômenos, como este, não é condicionada, em grande parte, por um léxico romântico específico que, ao longo do século XX, encontrou no cinema e na televisão potentes construtores e difusores, contribuindo para atribuir sentido a eventos diversos, mais ou menos absurdos como o aqui analisado.

Aqui, a perspectiva de Lauretis acerca das tecnologias de gênero aparece de forma mais expressiva. O programa de Sonia Abrão, em que o especialista convidado mostra-se "otimista" em relação a um desfecho feliz podendo culminar em casamento, encaixa-se na própria construção deste tipo específico de programa, direcionado prioritariamente ao público feminino e que, nesse sentido, constrói representações de gênero através da apresentação de determinados conjuntos de interesses e aspirações, como caracteristicamente "masculinos" ou "femininos". O programa é pensado prioritariamente para um público de donas de casa de classe média, não empregadas no mercado de trabalho formal, apresentando-lhes dicas de beleza, conselhos sobre relacionamentos amorosos, "fofocas" de personagens famosos, co- 
mentários sobre novelas, entre outros. Assim sendo, a fala do citado convidado, talvez mais do que expressar a sua própria perspectiva do evento, condiz com as supostas expectativas do público desenhado para esse tipo de programa, no qual a categoria gênero - sob uma visão profundamente estereotipada e enraizada no imaginário brasileiro - é o elemento central da elaboração.

O discurso da violência justificada pelo descontrole emocional, além de expressar um desnivelamento brutal nas relaçóes de poder entre homens e mulheres, reforça estereótipos de masculinidade que contrapóem "homens guiados pela razão" a mulheres "guiadas pela emoção". Mais do que isso, reproduz-se a crença de uma aptidão naturalizada das mulheres à gestão das emoçóes, especialmente em relações amorosas. Francesca Cancian (1986) argumenta que os ideais de amor construídos na sociedade norte-americana ${ }^{14}$ teriam um caráter "feminilizado", ao enfatizarem determinadas habilidades como apropriadas a um sexo ou ao outro: "Expressar sentimentos de ternura, ser gentil e sensível aos sentimentos de outros eram ainda qualidades ideais para mulheres e não para homens" (Cancian, 1986, p.695). Assim, a reação violenta à frustração amorosa masculina não apenas se encontra "justificada” pela inépcia naturalizada do homem na expressão de suas emoçóes, como ainda, neste imaginário romântico de sequestros amorosos, fugas e atos desesperados ${ }^{15}$, é, muitas vezes, notada como reiteração da intensidade do sentimento amoroso.

Em relação a isso, a montagem do filme, visando reforçar a crítica aos crimes passionais cometidos por homens contra mulheres, acaba descaracterizando uma fala do consultor da Polícia do Rio de Janeiro, Roberto Pimentel, à época do sequestro: "Existe também uma tendência mundial a respeito do tomador de refém passional. Ele não é economicamente motivado. Ele é mentalmente perturbado. Logo ele é imprevisível. Não se espera algo razoável, lúcido de uma pessoa que esteja sofrendo de paixão, de amor." No contexto dessa fala, o consultor critica justamente a estratégia adotada pela polícia de São Paulo, ao buscar a negociação racional com um sequestrador "imprevisível" e não "economicamente motivado". Convém lembrar que o depoimento de Roberto Pimentel é colocado no documentário, instantes após a cena em que o comandante da PM de São Paulo, em entrevista coletiva, argumenta que se escolheu não tomar uma iniciativa antes, por se tratar de um "garoto de 22 anos sem antecedentes criminais [sofrendo] de uma crise amorosa". A fala de Roberto Pimentel - um argumento a mais para a intervenção imediata da polícia militar, ao invés de estender negociações infrutíferas por cinco dias -, é logo ressignificada, na crítica de Analba Teixeira, em uma expressão de condescendência com o sequestrador. Não se pode negar que a mídia televisiva construiu e reiterou o discurso indulgente em relação a Lindemberg, enquanto alguém que estaria "sofrendo de amor". Contudo, especialmente ao deslocar de seu contexto o depoimento do consultor para reforçar uma crítica à cultura machista presente e atuante no episódio, o filme acaba comprometendo sua própria coerência interna e das críticas que ele propóe.

A questão é mais grave ao se levar em conta que as construçóes do amor, nos produtos difundidos e reiterados por diferentes mídias ao longo de décadas, configuraram situaçóes nas quais o amor se torna "o tema central da felicidade moderna" (Morin, 1973, p.131); sendo que essa centralidade é construída de forma desigual para mulheres em relação a homens:

A mística do príncipe encantado virá se inscrever em continuidade, levando as mulheres a crerem que o sentido de sua existência é algo escondido. Em uma existência vazia, o amor virá preencher essa falta. A mulher espera do homem uma confirmação de sua identidade, um reconhecimento, uma afirmação. [...] O jogo amoroso é idealização da fantasia do reconhecimento: "o outro me dará minha identidade... ele faz de mim alguém” (Chaumier, 1999, p.170).

Quando se trata de relacionamentos íntimos, ao contrário do discurso romântico idealizado, trata-se também de relaçóes de poder, numa acepção foucaultiana que, além de prever a possibilidade de resistência, é intrinsecamente relacional, jamais constituindo algo passível de ser "possuído" por uns em detrimento de outros. Ainda segundo o autor: 
A condição da possibilidade de poder, em todo caso, o ponto de vista que permite tornar seu exercício inteligível até em seus efeitos mais "periféricos" e, também, enseja empregar seus mecanismos como chave de inteligibilidade do campo social, não deve ser procurada na existência primeira de um ponto central, num foco único de soberania de onde partiriam formas derivadas e descendentes; é o suporte móvel das correlaçóes de força que, devido a sua desigualdade, induzem continuamente estados de poder, mas sempre localizados e instáveis (Foucault, 2009, p.103).

Mas, mesmo que se reconheça algum aspecto de poder nas relaçóes amorosas, geralmente, idealiza-se um equilíbrio simétrico entre os amantes, que possibilite a negociação de seus interesses tanto individuais, quanto compartilhados. De modo que, ainda se aprende a amar - com inconteste participação do cinema e da televisão -, sob uma perspectiva de que "toda forma de amor se torna sinônimo de amor romântico, ao ponto em que tenhamos todas as dificuldades em conceber, ainda hoje, outra forma de amor" (Chaumier, 1999, p.121).

A naturalização de crenças amorosas e do imaginário romântico na contemporaneidade se cruza com as construçóes históricas de gêneros e sexualidades, sobre as quais essas crenças se afirmaram e se legitimaram. Contudo, ao assumir essas crenças como resultado direto dessas referidas construçóes - especialmente condicionando-se sua leitura a uma perspectiva rígida e estática, como a do patriarcado -, perdem-se elementos culturais potencialmente decisivos na compreensão da violência contra mulheres, praticada sob os argumentos de passionalidade. Falta, portanto, investigar, de maneira mais aprofundada, os processos de significação das relaçóes amorosas e das emoções - não raramente controversas - nelas envolvidas, para além dos processos de significação de gêneros e suas hierarquizaçôes historicamente construídas. Especialmente, porque o imaginário e o léxico românticos, ainda que possam ter partido de bases heteronormativas, não se restringem a relacionamentos heterossexuais; sendo o mesmo válido para as relações e disputas de poder não assumidas em relacionamentos amorosos em geral.

\section{Consideraçóes finais}

O propósito da presente análise, mais do que reiterar a relevância do documentário, ou apontar seus elementos passíveis de crítica, foi apresentar uma inserção diferenciada para a problematização sociológica da violência contra a mulher, capaz de explorar temas a princípio subjacentes, embora importantes para a compreensão deste fenômeno, visando potencializar açóes voltadas a combatê-lo. Nestes termos, os temas subjacentes que orientaram nossa análise, de forma intricada e complementar, foram o lugar das mídias de comunicação baseadas no audiovisual - como o cinema e a televisão, sem ignorar, hoje, sua extensão às plataformas digitais -, na constituição da dimensão cultural das sociedades contemporâneas, bem como as percepçóes e significaçôes de amor [romântico], nessas sociedades, e como elas se apresentam e são manipuladas em contextos de "crimes passionais" e "crises amorosas".

O caso de Eloá talvez evidencie, de maneira espinhosa, o quanto a cultura televisiva está impregnada no cotidiano brasileiro. Não se trata de uma leitura elitista e legitimista dos capitais culturais, mas antes, de uma crítica ao lugar - cultural e politicamente falando - que a mídia televisiva ocupa na sociedade brasileira. Lugar esse que impacta também em como homens e mulheres aprendem e reproduzem visóes, crenças e discursos sobre relacionamentos amorosos. As evocações presentes no documentário a novelas e filmes não são acidentais; as novelas se destacam na produção audiovisual brasileira em relação a outros países. Gênero televisivo considerado secundário, barato e de mau gosto em outros países, a novela tem, no mercado audiovisual brasileiro, papel central, lançando atores e diretores ao estrelato, além de contar com significativo apelo popular.

Se analisarmos a grade de programação da emissora de TV aberta de maior audiência do país até o início dos anos 2000, notamos que sua maioria relativa é preenchida por novelas, incluindo reprises e minisséries de produção própria. Desse modo, a cultura novelística no Brasil também reside na forma de significar emoçôes e construir referências de gênero, as quais se manifestam inclusive na cobertura jornalística, desde que impregnadas, no senso comum, 
enquanto formas compartilhadas de percepção e interpretação da realidade. Essa cultura novelística, no Brasil, é, para muitos, indiscernível do próprio olhar sobre a realidade, o que contribui para que espectadores fiquem instigados com "cenas reais" dignas de um roteiro de novela, em que um homem comete uma "loucura de amor", embora o desfecho, diferentemente, tenha sido trágico.

Há, sem dúvida, um discurso que precisa ser desconstruído, em que a violência impetrada por homens contra mulheres apresenta-se justificada pela passionalidade e pela "crise amorosa". E, como se pôde observar nesta análise, o filme é bem-sucedido na construção de seu argumento nesse sentido. Não obstante, isso será insuficiente enquanto recusarmos - também por razões culturais - nossas próprias noçóes de amor como objetos de questionamento, crítica e investigação. E aqui, novamente lembramos de Lauretis (1994, p.209), quando ela afirma que "a construção do gênero se faz também por meio de sua desconstrução". Em contextos de violência, reduzir o discurso amoroso a mais uma expressão reiterativa de relaçóes hierarquizadas de gênero corresponde a preservar a aura - romântica - intocável do ideal amoroso e, consequentemente, atribuir apenas àquilo que recusa o ideal, uma explicação política e/ou científica. E, ainda que pareça contraditório, acreditamos que a compreensão da significação cultural e histórica da violência, em casos como este, passe necessariamente por uma compreensão da significação cultural e histórica do amor, bem como das emoçóes de maneira geral. Deste modo, concordamos com a assertiva de Grossi (1994, p.483), de que "é só 'desnaturalizando' o conceito de violência, e tirando-o do polo do masculino, que teremos instrumentos mais eficazes de luta".

Considera-se que o filme oferece contribuição importante para açóes educativas de conscientização a respeito de temas como o feminicídio, violência contra a mulher e relacionamentos abusivos; bem como para o debate e esclarecimentos sobre os mesmos. Ao instigar com a pergunta "Quem matou Eloá", o título do documentário é feliz ao sugerir, em princípio, três respostas que, ao final do filme, conjugam-se como parte de um fenômeno mais amplo e abrangente. A primeira sugestão é de que a pergunta poderia ser respondida pela imprensa e pelas emissoras de televisão, em suas intervençóes no contato e nas negociaçóes com o sequestrador. A segunda sugestão de resposta, menos explorada, seria atribuída à [falta de] ação da Polícia Militar de São Paulo, ao longo de todo o período de negociações. A terceira, que abrange e conecta as anteriores, seria o que, nos termos de Blay (2003, p.96), pode ser entendido como uma cultura machista, operando em diferentes instâncias - seja através do Estado, do sistema judiciário ou das mídias -, no sentido de reiterar como natural a subordinação de mulheres a homens, a ponto de conferir a estes, prerrogativas de propriedade e cerceamento do corpo e da vida daquelas. Por sua vez, essas características remetem à perspectiva da dominação patriarcal, apresentada por Saffioti (2004), enquanto sistema de dominação de homens sobre mulheres. Contudo, conforme argumentamos anteriormente, em concordância com Santos e Izumino (2005), esta seria uma perspectiva ainda insuficiente para a compreensão do fenômeno abordado pelo filme.

Assim, o enigma construído pelo filme sobre "Quem matou Eloá" é respondido por uma cultura machista social e historicamente estruturada, sustentada e alimentada, tanto pelo Estado (representado pela Polícia), quanto pela mídia (representada pela televisão). Contudo, ao enfatizar aqui o aspecto cultural, entendemos que este não se limita a uma forma simples e linear de dominação de homens sobre mulheres. Por isso, reiteramos uma perspectiva relacional de gênero para a análise do problema em tela, haja vista que, em sua dimensão cultural, esse machismo encontra diferentes espaços de reprodução, legitimação e naturalização, por agentes masculinos e femininos, heterossexuais ou não. Obviamente, isso não diminui a importância dos esforços no combate à referida cultura, do qual entendemos que o presente documentário não apenas faz parte, como apresenta grande contribuição pedagógica.

A partir da sequência final - em que várias mulheres transitam em um centro urbano, enquanto, em voz off, são lidos nomes de vítimas de feminicídio -, é possível interpretar que, em uma sociedade onde persistem traços dessa cultura machista e onde crimes de violência contra a mulher ainda são recorrentes e constituem um fenômeno social 
nada desprezível, nem vítimas e nem agressores possuem rosto, cor ou classe definida. Aqueles que impetram tal forma de violência não têm nome, mas seu gênero - bem como sua posição social correspondente a ele - é mais do que subentendido. $\mathrm{O}$ significado político que essa variedade de ato violento adquire é reiterado amiúde no filme. Falta-nos, contudo, uma maior compreensão - que este filme não nos oferece e nem se propóe a oferecer da rede de significados - igualmente históricos e sociais - que constituem as próprias relaçóes "amorosas" em que esses casos de violência encontram todas as suas condiçôes favoráveis de existência, enquanto práticas e crenças culturalmente valorizadas e reafirmadas. Ao ponto de a narrativa dominante na imprensa para conferir sentido ao caso - até o momento do disparo de Lindemberg - ser justamente uma narrativa de amor romântico.

\section{Notas}

1 Estamos cientes da problemática da definição de "violência contra as mulheres", debatida por Miriam Grossi (1994), e como várias expressóes - tais como "violência de gênero"; "violência conjugal" e "violência doméstica" - são frequentemente tomadas como sinônimos de "violência contra as mulheres", apesar de seus diferentes sentidos e contextos. Contudo, avaliando o caso em específico, tratado no documentário, entendemos que a expressão seja a mais cabível, embora, de acordo com a apresentação da autora, aproxime-se a uma situação de violência conjugal (Grossi, 1994, p.482).

2 Fonte: http://doctela.com.br/tv/quem-matou-eloa/. Consultado em 16 abr. 2019.

3 idem

4 idem

$5 \mathrm{O}$ único ponto de vista que poderia ser considerado um pouco diferente, no caso deste documentário, seria o do promotor de Justiça de São Paulo, Augusto Rossini, mas que não chega a constituir um contraponto à fala de nenhuma das demais comentadoras. No máximo, ele oferece o depoimento de alguém que teve participação direta no evento, atuando junto à polícia de Sáo Paulo durante as negociaçóes, apesar de ter expressado sua preocupaçáo e discordância com a forma como elas ocorreram.
6 Todas as citações de textos em língua estrangeira foram livremente traduzidas pelo próprio autor do presente artigo.

7 Tal como identificadas nos créditos do filme

8 Em relação a isso, destacam-se movimentos expressivos relacionados à quarta onda do feminismo no Brasil, como a Marcha das Vadias, de 2011; pautas incorporadas às manifestaçóes de junho de 2013; e diversas ações organizadas através de redes sociais, como twitter e Facebook, que, em 2014, contavam com uma quantidade consideravelmente maior de usuárias, do que em 2008.

9 Enquanto em 2008, apontava-se que apenas 18\% dos domicílios brasileiros contavam com acesso à internet, estes já correspondiam, em 2015, a mais da metade (51\%) dos domicílios. Cf.: http://data.cetic.br/cetic/ explore?idPesquisa=TIC_DOM. Consultado em 12. Mai. 2018.

10 O filme informa que, de acordo com Nayara, ele se vangloriava da visibilidade que estava atraindo para seu caso na televisão.

11 Chama atenção que, em um dos excertos da cobertura televisiva da época, percebe-se a insistência da imprensa em projetar a construção de um ato desesperado sobre o caso, inclusive quando o próprio sequestrador, ao telefone, recusa essa leitura: "Desespero? Se eu estivesse desesperado dava um tiro na cara e já era. Tô sem sentimento nenhum. Tô frio pra c...”

12 Em alusão ao ditado popular de que "Em briga de marido e mulher, não se mete a colher”, citado e contestado na fala da militante Analba Teixeira.

13 De acordo com o Atlas da Violência 2017 (IPEA; FBSP, 2017, p.37), "Enquanto a mortalidade de mulheres não negras teve uma reduçáo de 7,4\% entre 2005 e 2015, atingindo 3,1 mortes para cada $100 \mathrm{mil}$ mulheres não negras - ou seja, abaixo da média nacional -, a mortalidade de mulheres negras observou um aumento de $22 \%$ no mesmo período, chegando à taxa de 5,2 mortes para cada 100 mil mulheres negras, acima da média nacional."

14 E em grande medida incorporadas no Brasil, através do consumo de produtos culturais - programas de televisão, filmes, música e comerciais - importados dos Estados Unidos e, não raramente, reproduzidos nas produçóes locais. (Cf. MUANIS, 2014).

15 A esse respeito, ver ROUGEMONT, D., $O$ amor e o ocidente. 


\section{BIBLIOGRAFIA}

BLAY, Eva A. (2003), Violência contra a mulher e políticas públicas. Estudos Avançados, 17, 49:87-98.

CGI.BR/NIC.BR, Centro Regional de Estudos para o Desenvolvimento da Sociedade da Informação (Cetic.br), Pesquisa sobre o Uso das Tecnologias de Informação e Comunicação nos domicílios brasileiros - TIC Domicílios 2016. Disponível em: <http://data.cetic.br/cetic/explore?idPesquisa=TIC_DOM>, consultado em 12. Mai. 2018.

CANCIAN, Francesca. (1986), The feminization of love. In Signs, 4, 11:692-709.

CARRIÈRE, Jean-Claude. (1995), A linguagem secreta do cinema, Rio de Janeiro, Nova Fronteira.

CHAUMIER, Serge. (1999), La déliaison amoureuse, Paris, Armand Colin.

ESTEBAN, Mari Luz. (2011), Crítica del pensamento amoroso, Barcelona, Bellaterra.

FOUCAULT, Michel. (2009), História da sexualidade v. 1: a vontade de saber, Rio de Janeiro, Graal.

GROSSI, Miriam. (1994), Novas/Velhas violências contra a mulher no Brasil, in Estudos Feministas. N.E.: 473-483.

LAURETIS, Teresa. (1994), Tecnologia do Gênero, in H. B. Hollanda (org.), Tendências e impasses: o feminismo como crítica da cultura, Rio de Janeiro, Rocco.

IPEA; FBSP. Atlas da violência 2017. Disponível em: $<$ http://www.ipea.gov.br/atlasviolencia/down$\operatorname{load} / 2 / 2017$, consultado em 12. Mai. 2018.

LEI 13.104/2015. Texto Integral. Disponível em < http://www.planalto.gov.br/ccivil_03/_ ato2015-2018/2015/lei/l13104.htm, consultado em 20. Abr. 2019.

LEI 11.340/2006. Texto Integral. Disponível em <http://www.observe.ufba.br/lei_integra, consultado em 20 abr. 2019.

LOURO, Guacira Lopes. (2008), Cinema e sexualidade. Educação e Realidade,33, 1. jan-jun:80-98.

LUHMANN, Niklas (1991), O amor como paixão para a codificação da intimidade, Rio de Janeiro, Bertrand Brasil.
MENEZES, Paulo (2001), À meia-luz: Cinema e sexualidade nos anos 70, São Paulo, Editora 34.

MORIN, Edgar (1973), Cultura de massas no século $X X$, Rio de Janeiro, Forense Universitária.

MUANIS, Felipe (2014), Audiovisual e mundialização: televisão e cinema, São Paulo, Alameda.

ODIN, Roger (2012), Filme documentário, leitura documentarizante, in Significaçâa: Revista de cultura audiovisual, 37, 39:10-30.

PASINATO, Wânia. (2010), Lei Maria da Penha: Novas Abordagens sobre velhas propostas. Onde avançamos?, in Civitas, 2v. 10:216-232, Porto Alegre.

ROUGEMONT, Denis de. (1988), O amor e o Ocidente, Rio de Janeiro, Guanabara.

SABAT, Ruth. (2001), "Pedagogia cultural, gênero e sexualidade", in, Estudos Feministas, 1, 9: 9-21.

SAFFIOTI, Heleieth. (2004), Gênero, patriarcado, violência, São Paulo, Fundação Perseu Abramo.

SANTOS, Cecília Macdowell; IZUMINO, Wânia Pasinato. (2005), Violência contra as mulheres e violência de gênero: Notas sobre os estudos feministas no Brasil, in: E.I.A.L. Estudios Interdisciplinares de América Latina y El Caribe, 1, 16; 147-164.

SCOTT, Joan. (1995), "Gênero: uma categoria útil de análise histórica" in, Educação e Realidade, 2, 15 Porto Alegre.

SORLIN, Pierre. (1985), Sociologia del cine: La apertura para la historia de mañana, México, Fondo de Cultura Econômica.

WILLIAMS, Raymond. (2016), Televisão: tecnologia e forma cultural, Belo Horizonte, PUC Minas ;São Paulo, Boitempo.

Material audiovisual

LACERDA, Felipe; PADILHA, José. (dir.). (2002), Ônibus 174. Brasil, Zazen produçóes. 118 min., son., color.

KUBRICK, Stanley (dir.). (1971), Laranja Mecânica [A Clockwork Orange], Reino Unido/ EUA, Warner Bros. 138 min., son., color.

PEREZ, Lívia (dir.). (2015), Quem Matou Eloá, Brasil, Doctela. 24 min., son., color.

SALLES, João Moreira; LUND, Kátia (dir.). (1999), Noticias de uma guerra particular, Brasil, VideoFilmes. 57 min., son., color. 


\section{O DISCURSO DE AMOR NA VIOLENNCIA CONTRA MULHERES: ANÁLISE SOCIOLÓGICA DE “QUEM MATOU ELOÁ”}

\section{Túlio Cunha Rossi}

Palavras-chave: Violência contra as mulheres; Gênero; Sociologia do Cinema; Televisão; Relacionamentos íntimos.

O texto consiste em uma análise sociológica do documentário Quem matou Eloá (Lívia Perez, Brasil, 2015), sobre o sequestro e assassinato da adolescente Eloá Cristina, de 15 anos, por seu exnamorado, Lindemberg Alves, de 22 anos, em Santo André, SP, em outubro de 2008. O sequestro repercutiu na televisão brasileira, terminando com uma intervenção malsucedida da Policia Militar e a morte de Eloá. $\mathrm{Na}$ época, sustentou-se na televisão o discurso de que o crime resultava de uma "crise amorosa" de Lindemberg após o fim do relacionamento. $\mathrm{O}$ artigo entáo discute conexóes entre os processos de significação cultural tanto da violência contra as mulheres quanto dos relacionamentos amorosos e a participaçáo de meios de comunicação nesses processos. Adota-se a sociologia do cinema de Pierre Sorlin, buscando fragmentos de ideologia evocados no filme, enquanto este constrói uma crítica distanciada do caso em relação ao papel sensacionalista da cobertura televisiva à época.

\section{LOVE SPEECH ON THE VIOLENCE AGAINST WOMEN: A SOCIOLOGICAL ANALYSIS OF "QUEM MATOU ELOÁ"}

\section{Túlio Cunha Rossi}

Keywords: Violence against women; Genre; Sociology of film; Television; Intimate Relationships.

This paper consists of a sociological analysis of the documentary "Quem Matou Eloá" (Lívia Perez, Brazil, 2015), about the kidnapping and murder of 15-year-old teenager Eloá Cristina by her ex-boyfriend Lindemberg Alves, 22, in Santo André, SP, in October 2008. The kidnapping reverberated on Brazilian television, ending with an unsuccessful intervention by the Military Police and the death of Eloá. At the time, the television sustained that the crime resulted from a "love crisis" of Lindemberg after the breakup. The paper addresses connections between processes of cultural significance of violence against women and love relationships, just as the participation of the media in these processes. Pierre Sorlin's sociology of film is adopted, seeking fragments of ideology evoked in the film, while it builds a distanced critique of the case concerning the sensationalist role of television coverage at the time.

\section{LE DISCOURS DE L'AMOUR DANS VIOLENCE CONTRE LES FEMMES: ANALYSE SOCIOLOGIQUE DE « QUI A TUÉ ELOÁ "}

Túlio Cunha Rossi

Mots-clés: Violence contre les femmes; Genre; Sociologie du cinéma; Télévision; Relations intimes.

Le texte se compose d'une analyse sociologique du documentaire Quem matou Eloá (Qui a tué Eloá - Lívia Perez, Brésil, 2015), sur l'enlèvement et le meurtre de l'adolescente Eloá Cristina, 15 ans, par son ex-petit ami, Lindemberg Alves, 22 ans, à Santo André, SP, en octobre 2008. L'enlèvement a eu une grande répercussion à la télévision brésilienne et s'est achevé par une intervention inéficace de la police militaire et la mort d'Eloá. À l'époque, le discours soutenu par la télévision a été que le crime résultait d'une " crise d'amour " de Lindemberg liée à la fin de leur liaison amoureuse. L'article aborde ensuite les liens entre les processus de contenu culturel, aussi bien de la violence à l'égard des femmes que des relations amoureuses et la participation des médias à ces processus. La sociologie cinématographique de Pierre Sorlin est adoptée, tout en cherchant des fragments d'idéologie évoqués dans le film, tandis que ce dernier construit une critique lointaine de l'affaire par rapport au rôle sensationnaliste de la couverture télévisuelle de l'époque. 